\title{
Migration Emergencies and Multi-Level Governance at the EU-Turkey Border
}

\author{
Nefise Ela Gökalp Aras
}

\begin{abstract}
Since 2011, political, social, environmental, and economic instability in the Middle East and North Africa (MENA) region has sparked large transnational population movements that have stressed existing state and non-state migration management systems to capacity. This has created opportunities for new actors - including national and international non-governmental organisations (NGOs), intergovernmental organisations (IGOs), and even regional and municipal administrations - to assume roles traditionally performed by national governments. Against this background, this paper seeks to shed light on recent changes in Turkey's border governance, particularly concerning its relationship to the European Union (EU).

The paper focuses on the roles of and interaction between various local, international and supranational actors (both state and non-state). Drawing on concepts of governance, the paper critically analyses Turkey's approach to border management since 2011. It argues that the EU and the Syrian mass migration are the most significant forces of change in Turkey's border management, which seems to have become more inclusive and open to different actors such as NGOs or IGOs, and Turkish state actors exclusively assume a control function, while NGOs and IGOs are assigned a care function. It is informed by fieldwork conducted between July and November 2018 at the main sea border-crossing points of Turkey's Mediterranean coast.
\end{abstract}




\section{Introduction}

As of February 2020, there were 70.8 million forcibly displaced persons worldwide. ${ }^{1}$ This record number, combined with a spike in Syrian refugee numbers between 2012 and 2016, has brought global attention to the issue of mass migration. ${ }^{2}$ Lacking concerted global efforts to establish a permanent solution or coordinated approach to the refugee crisis, international responses have comprised mostly ad hoc initiatives. These include United Nations (UN) ${ }^{3}$ responses and regional and bilateral agreements mainly between destination countries, and occasionally with source or transit countries. The European Union (EU) has been at the forefront of such action in response to millions of refugees from the Middle East and North Africa (MENA) region arriving at European borders. ${ }^{4}$ The peak in the global refugee crisis has restored mass migration to the top of foreign policy agenda.

A Multi-Level Governance (MLG) approach has been unavoidable and the EU has emphasised "the need for new institutions, funding, re-interpreted principles of non-refoulement and sincere cooperation and concrete policies." ${ }^{5}$ The EU has spearheaded a series of initiatives in response to these developments, including the European Commission's European Agenda on Migration (2015) ${ }^{6}$ and its New Partnership Framework with Third Countries under the European Agenda on Migration (2016). ${ }^{7}$ With Turkey specifically, the EU created the EU-Turkey Joint Action Plan (JAP) in $2015^{8}$ and the EU-Turkey Statement of March 2016 (Statement). ${ }^{9}$ Similar to the UN initiatives seeking a global approach to the crisis, the EU has begun initiatives under the umbrella of "crisis governance." This is defined as "instantaneous, spontaneous and unconditional emergency relief granted gratuitously and charitably outside democratically approved processes [that] upset an already complex structure of migration governance."

\footnotetext{
${ }^{1}$ UNHCR, "Figures at a Glance," Website, United Nations High Commissioner for Refugees, available at: https://www.unhcr.org/figures-at-a-glance.html [last accessed 6 February 2020].

${ }^{2}$ Marion Panizzon and Micheline van Riemsdijk, "Introduction to Special Issue: Migration Governance in an Era of Large Movements, a Multi-Level Approach," Journal of Ethnic and Migration Studies, 2018, Vol 49 (8), p. $1225-1241$.

${ }^{3}$ Global meetings to address the problem and possible responses included the Supporting Syria Conference in London in February 2016, the World Humanitarian Summit (WHS) in May 2016 in Istanbul, the UN General Assembly High Level meeting in September. The latter brought countries together around a plan resulting with the New York Declaration for Refugees and Migrants.

${ }^{4}$ Marion Panizzon and Micheline van Riemsdijk, op.cit., 2018, p. 4-5.

${ }^{5}$ Ibid.

${ }^{6}$ European Commission, “A European Agenda on Migration,” Website, European Commission, 15 May 2015 , available at:

https:/ec.europa.eu/home-affairs/sites/homeaffairs/files/what-wedo/policies/european-agenda-migration/backgr ound information/docs/glossary_for_the_european_agenda_on_migration_en.pdf [last accessed 19 February 2019].

${ }^{7}$ European Commission, "A New Partnership Framework with Third Countries under the European Agenda on Migration," Website, European Commission, 7 June 2016, available at: https://eurlex.europa.eu/resource.html?uri=cellar:763f0d11-2d86-11e6-b497-01aa75ed71a1.0001.02/DOC_1\&a mp;format=PDF [last accessed 4 February 2018].

8 European Commission, "The EU-Turkey Joint Action Plan," Website, European Commission, 15 October 2015, available at: http://europa.eu/rapid/press-release MEMO-15-5860 en.htm [last accessed 7 April 2019 ].

${ }^{9}$ European Council, "The EU-Turkey Statement," Website, European Council, 18 March 2016, available at: https://www.consilium.europa.eu/en/press/press-releases/2016/03/18/eu-turkey-statement/[last accessed 7 April 2019].

${ }^{10}$ Streeck 2017 and Menéndez 2016 cited in Marion Panizzon and Micheline van Riemsdijk, op.cit., 2018, p. 5.
} 
The Syrian mass migration has created far-reaching consequences for all receiving countries, but most importantly for the three largest host countries: Turkey, Lebanon, and Jordan. Among these, Turkey hosts the highest number of registered Syrian refugees - over 3.5 million, amounting to $64.4 \%$ of the total concerning the displaced population as of 30 January 2020. ${ }^{11}$ This has become one of Turkey's most pressing domestic and foreign-policy challenges with significant implications for migration governance. Cross-border flows of refugees into Turkey since 2011 have caused changes in Turkey's approach to border management and asylum governance, including new legislation, protocols, regulations, and policies in relation to Syrian arrivals. All of these changes reflect the EU's desire to stem refugee arrivals on European shores. ${ }^{12}$ Irregular and forced migration ${ }^{13}$ are closely linked, as statistics on irregular migration illustrate. In 2011, Turkish law enforcement apprehended 44,415 individuals crossing its borders. This rose to 454,662 in 2019. ${ }^{14}$ The way in which migrant cases are "processed" upon arrival makes a significant difference to their determined status and future mobility, making Turkey's border management a crucial process for millions of people.

This paper analyses changes in Turkey's border management since 2011. Although border management has complex phases such as pre-entry measures, border checks and controls, and post-entry measures; this paper focuses on actions taking place at the border. Specifically, it focuses on the concept of "governance" and the new system of managing the EU-Turkey border relations, focusing on the roles and interactions of local, international, and supranational state and non-state actors. The paper argues that the EU and mass migrations are the most significant forces of change in Turkey's border management, which seems to have become more inclusive and open to different actors such as non-governmental organisations (NGOs) or intergovernmental organisations (IGOs). In this regard, this paper analyses changes in border management through a "division of labour," where Turkish state actors exclusively assume a control function, while NGOs and IGOs are assigned a care

\footnotetext{
${ }^{11}$ UNHCR, "Total Persons of Concern by Country of Asylum," Website, United Nations High Commissioner for Refugees, 2 May 2019, available at: https://data2.unhcr.org/en/situations/syria [last accessed 6 February 2020].

${ }^{12}$ Nefise Ela Gökalp Aras and Zeynep Şahin Mencütek, "Evaluation of Irregular Migration Governance in Turkey from a Foreign Policy Perspective,” New Perspectives on Turkey, 2018, Vol. 59, p. 63-88.

${ }^{13}$ Stephen Castles defines the nexus between migration and asylum as "a fluid and blurry relationship between the political construct of migrant and asylum seeker." See: Stephen Castles, "The Migration-Asylum Nexus and Regional Approaches," in Susan Kneebone and Felicity Rawlings-Sanae (eds.), New Regionalism and Asylum Seekers: Challenges Ahead, London, Berghahn Books, 2007, p. 25-42. There is also a nexus between irregular and forced migration. People who are seeking asylum and would qualify as refugees or who are the subject of international protection may undertake irregular moves or economic and voluntary motives may resort to asylum routes in the hope of gaining legal stay. See: Anna Triandafyllidou and Angeliki Dimitriadi, "Governing Irregular Migration and Asylum at the Borders of Europe: Between Efficiency and Protection," Imagining Europe (6), Istituto Affari Internazionali; Criminal Justice, Borders and Citizenship Research Paper No. 2602712, 2014, Vol 6, p. 1-34.

${ }^{14}$ DGMM, "Number of Irregular Migrants Who Have Been Captured by Years," Website, Republic of Turkey Ministry of Interior Directorate General of Migration management, 29 January 2020, available at: http://www.goc.gov.tr/icerik6/irregular-migration $915 \quad 1024 \quad 4746$ icerik [last accessed 6 February 2020].
} 
function.

While changes in Turkish border management represent a model of MLG in a period of crisis that includes multi-level non-state actors, these actors have little power to influence or criticise unlawful practices while exercising their care roles, lest they risk closure or sanctioning. Actors who gain permission to work alongside the Turkish state are those who implicitly or explicitly consent to and participate in state policies without objection. Additionally, Turkish border management interacts with EU border management to stop irregular migrants, mixed flows or mass migration that the EU considers external threats or "unwanted" population, as revealed in the EU-Turkey Readmission Agreement (EUTRA, 2013) and the EU-Turkey Statement (2016).

Against this background, the paper investigates the following questions: Which actors and institutions currently dominate Turkey's border management - particularly at the EU border and the Mediterranean Sea border? Does MLG adequately explain changing border management processes in Turkey? Does the case of Turkey's EU borders show that states are ceding power over border management or merely changing its outward form? To understand changing border management in Turkey, this paper refers to institutional, physical, and administrative mechanisms and knowledge structures that enhance and maintain the exercise of power. This paper focuses on the role of civil society and IGOs, examining the extent to which their roles in official border management policies and practices are in accordance with human rights. The withdrawal of the Turkish state from MLG in favour of increasingly centralised control, endangers migrants' human rights due to the division of labour between "control" and "care." However, we must question the veracity of MLG concepts in describing real and permanent change. This paper incorporates an understanding of the "mentalities" of government to show that the role of non-state actors in shaping and carrying out global governance functions does not represent a real transfer of power from the state to non-state actors.

This paper draws on both secondary research and fieldwork. ${ }^{15}$ Secondary research included reports published by IGOs and NGOs, scholarly analysis of policy measures, recent data, and official documents and statements. Fieldwork carried out between August 2018 and November 2018 provided primary data for this study. The fieldwork included 21 semi-structured meso-level interviews, participant observation, and focus groups in three Turkish cities - Izmir, Ankara and Çanakkale. ${ }^{16}$ The interviews were conducted with high-level government officials in ministries and directorates - namely, the Directorate

15 Part of the Horizon 2020 project "RESPOND: Multi-level Governance of Mass Migration in Europe and Beyond Project." See: RESPOND migration, Website, RESPOND, available at: https://www.respondmigration.com/ [last accessed 4 May 2019].

${ }_{16}$ The paper focuses on Izmir, a Turkish border city that has long been a transit hub for migrants heading to Europe (mainly Greece) and thus a principal place of "exit" from Turkey to Europe. Ankara - far from the border and with no significant refugee population - is still a crucial site for fieldwork, since it is the Turkish capital and the centre of policy development. It hosts several ministries and directorates (e.g. the DGMM), foreign delegations, and IO headquarters. All the EU-level institutions are Ankara-based, as is the UNHCR Turkey office, and other IGOs and significant NGOs have their headquarters there as well. Finally, the Çanakkale - with its proximity to both Izmir and Istanbul, and the Aegean island of Lesbos in Greece - was included, with a particular focus on the town of Küçükkuyu. 
General of Migration Management (DGMM) and the Provincial Directorate of Migration Management (PDMM). Provincial administrators in local government bodies (municipalities and city councils) and law-enforcement agencies (the Izmir Gendarmerie Department of Anti-smuggling and Organised Crime and the Izmir Provincial Directorate for Combating Migrant Smuggling and Human Trafficking) were also interviewed. Finally, experts from IGOs such as the International Organization for Migration (IOM) and the United Nations High Commissioner for Refugees (UNHCR), representatives of NGOs and lawyers from the bar associations dealing with migrant cases, were interviewed. The data was analysed using the qualitative data analysis software Nvivo12 Plus.

\section{Multi-level governance in Turkey: from rigid to dynamic linear models}

Through the 1990s, "global governance" became a core interest of academics and industry practitioners, producing substantial literature on the changing roles of sovereign states in governing global or transnational affairs. Global governance can be understood as the combination of different ways that individuals and institutions, public and private, manage common affairs. This field developed the concept of "multi-level governance," as understood by Hooghe and Marks, ${ }^{17}$ which is helpful in analysing evolving border management in Turkey since 2011. MLG provides an explanatory framework to understand the re-allocation of authority beyond traditional and representative institutions, where border-management is understood as the domain of the sovereign state. MLG refers to "systems of governance where there is a dispersion of authority upwards, downwards and sideways between levels of government - local, regional, national and supra-national - as well as across spheres and sectors, including states, markets and civil society. ${ }^{18}$

This paper's analysis of non-state actor roles in humanitarian responses shows how authority has been dispersed from the central and national government to intergovernmental or even supranational institutions and subnational governments. ${ }^{19}$ In Turkey, these changes have taken place more rapidly in response to geopolitical events since 2011 and, in particular, the "European Refugee Crisis" of 2015. They primarily relate to changes in jurisdiction over borders which have involved intergovernmental (i.e. UN) and supranational (i.e. EU) and subnational (i.e. NGOs and local government) actors.

\footnotetext{
17 Their argument can be summarised as "governance must operate at multiple scales in order to capture variations in the territorial reach of policy externalities. Because externalities arising from the provision of public services vary immensely - from planet-wide in the case of global warming to local in the case of most city services - so should the scale of governance. To internalise externalities, governance must be multi-level." This is the core argument for multi-level governance. See: Liesbet Hooghe and Gary Marks, "Types of Multi-level Governance," Website, European Integration Online Papers, Vol 5(11), 2001, available at: http://eiop.or.at/eiop/texte/2001-011a.htm [last accessed 1 May 2019]; Liesbet Hooghe and Gary Marks, "Unravelling the Central State, But How? Types of Multilevel Governance," American Political Science Review, 2003, Vol. 97 (2), p. 233-243.

${ }^{18}$ Katherine Daniell and Adrian Kay, "Multi-level Governance: An Introduction," in Katherine A. Daniell and Adrian Kay (eds.), Multi-level Governance: Conceptual Challenges and Case Studies from Australia, Canberra, the Australian National University Press, 2017, p. 3-32.

${ }^{19}$ Liesbet Hooghe and Gary Marks, op.cit., 2001.
} 
Hooghe and Marks focus on the dispersion of migration governance - which, like border controls, were previously under the state monopoly - across multi-level jurisdiction can be broken down into two types, seen below.

Table: Types of Multi-Level Governance (MLG) ${ }^{20}$

\begin{tabular}{|l|l|}
\hline MLG Type 1 & MLG Type 2 \\
\hline General purpose jurisdictions & Task specific jurisdictions \\
\hline Non-intersecting membership & Intersecting membership \\
\hline Jurisdictions at a limited number of levels & $\begin{array}{l}\text { No limit to the number of jurisdictional } \\
\text { levels }\end{array}$ \\
\hline System-wide architecture & Flexible design \\
\hline
\end{tabular}

Type I MLG refers to fixed and established jurisdiction at various levels - local, regional or international that are more or less permanent. Such a view accommodates the presence and engagement of a range of non-state actors within the field. Type II MLG, by contrast, consists of "specialised jurisdictions" that mainly operate across the afore-mentioned levels. Type II MLG also reflects a more complex and fluid patchwork of overlapping jurisdictions, as argued by Paninzon and van Riemsdijk. ${ }^{21}$ Therefore, Type II is more task-specific and flexible since it is based on changing needs. In this regard, Type II MLG accommodates crisis and provides a framework for understanding how crisis influences institutional and actor interactions.

Paninzon and Van Riemsdijk refer to Type II's "blurring" of linear models of governance, arguing that this type represents more complex, unpredictable, and dynamic relationships between different jurisdictions and actors. Thus, Type II MLG distributes risk and responsibility among different levels and actors. Looking specifically at migration, it allows states to invite non-state actors into the process on a case-by-case basis in times of crisis, with a return to the normal state of affairs once the crisis is over.

MLG considers the emergence and influence of international or transnational actors as indicative of major transformations in the positioning of states in areas traditionally considered solely the domain of the state. While it is clear that NGOs, IGOs, and other new MLG actors have been allocated specific functions and are called on to play a role in border management, as Scholte states, the state-authorised presence of these actors has not generated change that is profound enough to alter structural characteristics, the modus operandi, or normative contents of state policies. ${ }^{22}$ Accordingly, this paper argues that non-state actors do not challenge the power of the state in any policy domain, and that they are in fact "licenced" to operate in their domains by the state itself.

Moreover, states engage these actors for their provision of capacity building, expertise, and financial support of border management in a form of "sub-contracting." This is mainly to assume the role of "care" provision within the state's broader remit to "care for and control"

\footnotetext{
${ }^{20}$ Liesbet Hooghe and Gary Marks, op.cit., 2003, p. 236.

${ }^{21}$ Marion Panizzon and Micheline van Riemsdijk, op.cit., 2018, p. 7.

${ }^{22}$ Scholte 2011, cited in Schiavo, 2014, p. 193.
} 
subject populations. Thus, non-state actors are not balancers of state power, but rather sub-contractors of state authority in given policy domains in which their expertise is called for. Both "care and control" are parts of humanitarian governance, which states - including Turkey - are obliged to undertake at the border. In this understanding, control is still the task of the state, but care is shared among new actors.

Regarding the "care and control" obligations of states, it is important to note that "humanitarian borders" can be defined as "a complex assemblage, comprising particular forms of humanitarian reason." ${ }^{23}$ As a consequence of the high number of incidents and migrant deaths at borders - especially sea borders - "care" in the form of on-water search and rescues, has been framed in recent years as a humanitarian intervention to save lives. This is where non-state actors' roles as "subcontracted care providers" emerge, with such organisations engaging in humanitarian border control practices to ensure the safety and well-being of migrants. IGOs and NGOs also practice humanitarian functions that are designed to reinforce and reproduce state sovereignty. In this way, the state shares its responsibility to "care" and reduces its risk - remaining the final arbiter for the logistics and legality of non-state actors' activity - while retaining its control function.

Turkey - a middle-income country tasked with significant responsibility (and thus cost) in migration control - draws heavily on technical support and capacity building and financing from intergovernmental organisations, such as the UN and the EU. However, the EU's influence in particular is highly politicised as "although the EU preaches the respect of human rights and compliance with international human rights law and asylum regime, in practice not only irregular transit migrants, but also mass influxes of refugees and asylum seekers who are under international protection are targeted as the "unwanted" population in the mixed flows." 24

\section{Complex National and International Dynamics underlying Turkey's Border Management}

Turkey borders eight countries and its geographic position between Europe and the Middle East, historical links with neighbouring countries, and difficult topography, have made its borders particularly permeable and hard to control. ${ }^{25}$

Border management is a central theme in the EU-Turkey relations and the EU has been one of the most important actors driving change since the 2000s. As an EU candidate country, Turkey must synchronise its border governance with the EU acquis ${ }^{26}$ as a condition of

${ }^{23}$ Walters 2011, cited in Beste İşleyen, "Turkey's Governance of Irregular Migration at European Union Borders: Emerging Geographies of Care and Control," Environment and Planning D: Society and Space, Vol. $36(5), 2018$, p. 852.

${ }^{24}$ Nefise Ela Gökalp Aras, "A Bio-political Governance: The European Union's Policy on Irregular Transit Migration at the Borders," in Assel Tutumlu and Gaye Güngor (eds.), International Political Economy: Multilateralism in Global Governance: Formal and Informal Institutions, Berlin, Peter Lang Publishing, 2016, p. 197.

${ }^{25}$ Deniz Sert, “Turkey’s Integrated Border Management Strategy,” Turkish Policy Quarterly, 2013, Vol. 12 (1), p. 173-179.

${ }^{26}$ European Council, "The Treaty of Amsterdam Protocols," Website, International Democracy Watch, 2 October 
membership. This includes compliance with the Schengen Area conditions. ${ }^{27}$ The EU's principal objective in migration governance is to protect the population inside the Schengen Area from external threats, including "unwanted" population movements. As the Schengen Area effectively abolishes internal borders within the EU, an "Integrated Border Management" (IBM) ${ }^{28}$ system has emerged as the principal border protection regime.

In this context, the EU has demanded that Turkey strengthens its border management to adequately implement the Schengen Convention (1985). The EU has deployed this argument as the driving rationale for international border management cooperation between Brussels and Ankara. ${ }^{29}$ This includes "inter-agency cooperation" - which refers not only to state actors but to cooperation between all actors involved in border issues. ${ }^{30}$ IBM then reflects a multi-faceted system of border management cooperation among both state and non-state actors. It can be said that to an extent, Turkey no longer has completely sovereign control over its border governance - this is key among long-term forces changing border-management in Turkey.

In addition to the EU requirements, instabilities within neighbouring countries, long-standing irregular influxes of people from Afghanistan, Iraq, Iran, and Africa, and since 2011, the Syrian refugee crisis, all challenge Turkey's border management. Following the Arab uprisings of 2011, an initial "open door policy" - when Turkey welcomed all Syrian refugees fleeing the conflict - led to an increase of fear regarding irregular migration and asylum applications to the EU. This saw Turkey take on an important role as gatekeeper of "Fortress Europe," particularly after the EU started to frame the issue as a refugee "crisis" in 2015.

Part of the EU response has been a new discourse on borders and migration governance, using humanitarian justifications for securitisation. This is visible in joint statements with Turkey such as the Joint Action Plan (JAP) adopted in $2015^{32}$ and the EU-Turkey Statement of 2016. For example, the JAP states that it aims to address the "massive influx of persons" through humanitarian assistance, legal, administrative and operational capacity-building along with cooperation in intelligence and information exchange. While multi-layered border management in Turkey can be partly explained with the impact of the EU, it has also been affected by both domestic concerns and Turkish foreign policy. ${ }^{33}$

http://www.internationaldemocracywatch.org/attachments/313 Amsterdam\%20Treaty\%20-\%20Protocols $\% 201$ 997.pdf [last accessed April 03 2019]

${ }^{27}$ Deniz Sert, op.cit., 2013, p. 176.

${ }^{28}$ Created by the Council Regulation 562/2006/EC of 15 March 2006.

${ }^{29}$ Deniz Sert, op.cit., 2013, p. 179.

30 IOM, "The International Organization for Migration and Integrated Border Management," Website, International Organization for Migration, 2015, available at: https://www.iom.int/sites/default/files/our_work/DMM/IBM/updated/05_FACT_SHEET_Integrated_Border_M anagement_2015.pdf [last accessed 3 May 2019].

31 Bianca Benvenuti, "The Migration Paradox and EU-Turkey Relations," IAI Working Papers, 17 January 2017, available at: http://www.iai.it/sites/default/files/iaiwp1705.pdf [last accessed 10 April 2019].

${ }^{32}$ European Commission, “The EU-Turkey Joint Action Plan,” op.cit., 2015; European Council, op.cit. 2016.

33 Gerda Heck and Sabine Hess, "Tracing the Effects of the EU-Turkey Deal the Momentum of the Multi-layered Turkish Border Regime," Movements Journal for Critical Migration and Border Regime Studies, 


\section{Key Actors and Changes in Turkish Border Management since 2011: EU Demands and Full Control}

At present, there are over 20 state actors sharing responsibility for Turkish border management and migration control. ${ }^{34}$ Their responsibilities are laid down in over 25 different legal regulations. The main coordinating roles belong to branches of the Turkish military and border agencies within the Ministry of the Interior, the Ministry of Foreign Affairs, and the Ministry of Customs and Trade.

Primary responsibility for Turkey's land border management lies under the Land Forces Command of the Turkish Armed Forces (TAF). The Gendarmerie General Command and Turkish police also coordinate closely on land borders. Turkey has a vast coastline and maritime border management is covered by the Turkish Coast Guard Command (TUCG). Also, the Directorate General of Security of the Ministry of Interior and the National Intelligence Organisation have authority to conduct cross-border operations and to gather intelligence concerning border control.

Under the influence of the EU, the security-centric nature of Turkish law enforcement has shifted somewhat toward a more civil structure. This aligns with the suggested multi-stakeholder structure of the IBM project, and the increasing popularity of the idea of border "governance" since the 2000s, when Turkey began the process of accession to the EU.

Responding to EU demands for more civilian actors within border management, the Task Force for Asylum, Migration and External Borders Protection was the first civilian agency established in 2002. This has functioned as the "Department of Border Management" since 2015. In parallel, the Directorate General of Migration Management (DGMM), established in 2013, has been central to "de-securitisation." It has and facilitated the collaboration of non-state and civil society actors as an alternative to the dominance of security and law enforcement institutions. The Disaster and Emergency Management Authority (AFAD) of the Ministry of Interior - another civilian actor - has taken the lead in managing temporary accommodation centres (refugee camps) for Syrians near border cities. Municipal councils also considered civilian actors - provide first-response emergency and humanitarian aid in the border regions. Some semi-official associations, such as the Turkish Red Crescent (TRC, Kızılay), which has a "Migration and Refugee Services Department," have also been involved.

The IOM has arguably been the most active border management intergovernmental organisation in Turkey, particularly since 2011. The United Nations High Commissioner for Refugees (UNHCR) also plays a significant role. The UNHCR promotes "protection-sensitive

2017, Vol. 3 (2), p. 35-56; Firat Genc, Gerda Heck, and Sabine Hess, "The Multi-layered Migration Regime in Turkey: Contested Regionalization, Deceleration and Legal Precarization," Journal of Borderlands Studies, 2018, Vol 34 (4), p. 489-508.

${ }^{34}$ For the detailed report regarding border management and migration controls in Turkey, see Nefise Ela Gökalp Aras and Zeynep Şahin Mencütek, Border Management and Migration Controls Turkey- Country Report, Multilevel Governance of Mass Migration in Europe and Beyond Project (\#770564, Horizon2020) Report Series, 2019, available

at: https://www.respondmigration.com/wp-blog/border-management-migration-controls-turkey-report. 
border management and access to asylum procedures for refugees and asylum seekers, including those in removal centres, inter-alia by working to improve access to information and legal assistance." ${ }^{35}$

Additionally, many NGOs have taken on border-management roles providing humanitarian responses and care. This has particularly been the case since the scale of the Syrian crisis overwhelmed state actors' capacities in infrastructure, personnel and training. While NGOs engage in such activities, they still rely on Turkish state permission to launch and carry out operations under particular conditions. These actors have differing forms and levels of cooperation with the state, and respond to various needs as determined by the state. Thus, the state decides the timing, scope, and forms of migrant control; while migrant care responsibilities are shared by selected NGOs and IGOs.

\section{Actors Taking Up "Care" Functions}

As of 2015, in response to the crisis, new IGOs as well as NGOs started opening offices in Izmir. IGOs such as the IOM and UNHCR were the most visible new actors in the field. In Izmir, IGOs mainly provide humanitarian aid, interpret, consult on international protection and legal advice, identify vulnerabilities, and support logistics and infrastructure in coordination with local NGOs. In Izmir the IOM is the most active IGO at important border-crossing points, providing support for both law enforcement and other state actors. For example, the IOM has a collaboration agreement with the TUCG's Aegean Region Command. Since border management and migration control cover mixed flows, the IOM operates both over a large distance and at very high capacity. Its mobile teams also work in other locations along the Aegean coast. At border-crossing points, the IOM is active with outreach teams but also as the first contact with immigrants once they are apprehended by Turkish law-enforcement actors. The IOM provides interpreting and humanitarian aid support, especially water, food packages, blankets and clothes. At the same time, they support state security personnel in identifying vulnerabilities and ad-hoc consulting. IGO respondents also mentioned that in addition to immigrants and refugees, security personnel sometimes received support with drinking water and other fundamental needs.

The UNHCR supports the capacity building of the PDMM, particularly in training experts and infrastructure upgrades where Syrians are provided with services, such as setting up mobile toilets and shade in registration sites. In Izmir, the UNHCR does not work at border-crossing points directly but supports and funds a Turkish NGO, the Association for Solidarity with Asylum and Refugees (ASAM), which works closely with the government. The majority of interviewees stated that the Turkish state tried to keep migrant entries under its full control without hindering the activities of non-state actors. According to NGO representatives, this can be attributed to Turkey's security concerns. For example, Turkey avoids asking the UNHCR for support of border crossings and did not allow the UNHCR access to the border points, except occasionally when permission was provided by central

\footnotetext{
${ }^{35}$ UNHCR, “Turkey Fact Sheet," Website, United Nations High Commissioner for Refugees, September 2018, available at: https://data2.unhcr.org/en/documents/download/66510 [last accessed 10 May 2019].
} 
authorities. During mass border crossings, IGOs and large NGOs had only been allowed to support local implementers delivering humanitarian aid to recently arrived Syrians.

Regarding NGOs, following 2015, some national NGOs such as ASAM developed whole new branches, while others developed new projects such as the Association for Solidarity with Refugees (Mülteci-Der) collaboration with the Danish Refugee Council or ProAsyl. ASAM is a major NGO presence in Turkish border governance. Interviews with representatives in both Izmir and Ankara revealed that ASAM has offices from Edirne (at the Bulgarian land border) to Bodrum (on the Mediterranean Sea). Like the IOM, they provide interpreters, lawyers, and social workers and also deploy mobile teams - including a "Mobile Counselling Team (MCT)" - modelled on the IOM's outreach teams.

While the IOM has operations with the TUCG, ASAM focuses on land operations and the interaction between borders. Thus, their principal points of coordination and collaboration are with the relevant state agencies such as the Gendarmerie and other security forces. In Izmir they provide services such as social and legal counselling, assisting asylum seekers and refugees with UNHCR processes, identifying vulnerable cases, reporting push-back cases and incidents, and distributing food and non-food items. ASAM provides humanitarian aid through one main depot, which is critically important for local and international NGOs and security actors. It also provides interpreters, social workers and humanitarian aid kits to security forces and the Gendarmerie. ASAM respondents said that collaboration based on good relations and communication was possible without official approval, and that this was ideal as it facilitated cooperation while avoiding slow bureaucracy. ${ }^{36}$

The Izmir Bar Association (IBA) provides extensive support to people under administrative detention at removal centres. After their release from the centres, these cases must await deportation. Many cannot access asylum due to a lack of documentation and information in removal centres. Actors like the IBA work to provide fair access to the asylum system in periods of high demand. This role is also considered care, under a humanitarian and rights-based approach.

\section{A Highly Constraining Context for NGOs and INGOs}

In Izmir, one of the fieldwork sites, border management stakeholders were not adequately prepared for their tasks in personnel, capacity or division of labour. Many of them were not even present in Izmir before the spike in Syrian arrivals in 2015. The following quote from a local journalist shows the impact of the high numbers at the Aegean border in Küçükkuyu, Çanakkale, where border crossings peaked:

"I could see 21 boats at the same time on the sea, through my camera lens. In 2015-2016, the border-crossing started here [in Küçükkuyu] intensively. It was shocking. The coast guard was struggling because the sea was full of boats and

\footnotetext{
${ }^{36}$ Interview (SRII-Meso-Izmir-12) by author with the representative of the regional coordinator of a national NGO, Izmir, 24 October 2018.
} 
people. What could they do? On land, migrants set up a camp. Can you believe that? On [just] five acres of land." ${ }^{37}$

Interviews demonstrated that the division of labour among the various actors was particularly challenging at the peak of the crisis in 2015. Many relevant institutions were not yet set up, and those that were, were facing significant challenges responding to the high numbers of transit migrants in urban centres, as well as at border-crossing points.

"When we started here [Izmir, 2015], we had a population of 47,000 Syrians. Then, there was an explosion in border crossings in the summer of 2015. By the end of the summer, there were 97,000 registered Syrians here [Izmir]. When we started, there were 1,00o people queuing [for help] at our door. There was no information regarding access to services. The DGMM in Izmir was not yet set up to work - that role was being undertaken by the police's foreign branch. ${ }^{38}$

While undertaking their "care" functions, respondents from NGOs and IGOs were careful in criticizing migration policies, because of fear that bilateral agreements needed to work with state actors might not be renewed. Some NGOs said that they had been excluded from the process when previously active agreements were not renewed. On the other hand, some said that the state excluded them from the process early on, on account of being too outspoken. Bilateral agreements are temporary, meaning that both IGOs and NGOs have an incentive to be careful raising concerns about policy measures. The interviewees stated that they were afraid of not having collaboration protocols renewed. The majority of interviewees said that access to the field and being able to collaborate was their organisation's highest priority so they were often willing to cooperate with questionable policies.

"It is so fragile. We have to be careful, because we are given permission to some areas, where any civilian can enter. For being able to continue our activities, we need to keep the balance. We are so careful, and without criticizing. But this is Turkey, everything can happen, thus we have to be careful."

Fieldwork interviews showed actors' clear reliance on state-authorised protocols, with the state being selective in terms of which NGOs it chooses to authorise. However, in some cases, collaboration based on existing relationships continues, even without formal cooperation protocols. For example, while the IOM has not had a mandate to provide support for readmitted immigrants since the UN withdrew support for the EU-Turkey Statement, ${ }^{40}$ it continues to provide such humanitarian aid and counselling "unofficially." This shows how collaboration and governance are needs-based and crisis-driven, with the Turkish state remaining the ultimate arbiter.

\footnotetext{
${ }^{37}$ Interview (SRII-Meso-Küçükkuyu/Çanakkale-06) by author with the local journalist, Izmir, 15 October 2018.

${ }^{38}$ Interview (SRII-Meso-Izmir-02) by author with the regional coordinator of an IGO, Izmir, 14 August 2018.

${ }^{39}$ Interview by author with the representative of the representative of the regional coordinator of a national NGO, Izmir, 14 August 2018.

${ }^{40}$ In practice, the readmissions have been processed under the limited terms of the Statement. Turkey in any case suspended the implementation of the Readmission agreements for the third-country nationals for political reasons.
} 
In addition, some state officials mentioned fear and pressure within their institutions after the coup attempt of 15 July, 2016. Subsequent increased securitization in the field was commonly noted by interviewees, and has been one of the most important limitations for Turkey's civil transition in MLG frameworks of migration.

"Our borders are quite political. Yes, there are international agreements, but with a word of one from Ankara [government], all the border policy can change. I have seen this a lot after the deal [the Statement]. Current decline of the border crossings is related to the directives from Ankara. I know very well that the Coast Guard is doing everything possible. "Let them cross period" has passed, because there is a lot of pressure on them [the Coast Guard] Because there is a lot of pressure on them because of the coup attempt." ${ }^{, 1}$

Some local and international NGOs were shut down in the wake of the 2016-2017 state of emergency and related decrees. The respondents explicitly noted the negative impact of the July 2016 coup attempt and the following state of emergency period. This period revealed that the state was still the ultimate arbiter over all levels of border management, with implicit pressure placed on all to comply with state policies. For example, in 2017, all Mercy Corps branches in Izmir were forcibly closed ${ }^{42}$ and cooperation between ASAM and the DGMM was abolished. This latter case was more surprising given that ASAM had been working actively as a part of Turkish border management, but in 2019 was declared as an organisation with links (iltisakh) to terrorism. ${ }^{43,44}$

Many interviewees in Izmir mentioned major problems involved in voluntary returns. According to regulations, the UNHCR should occupy an observer role alongside other civil society actors to assess the voluntariness of returns from refugee camps. However, many interviewees representing different civil society actors said that they did not want to take part in this process because their role had been to facilitate procedures which some doubted were truly "voluntary." If the returns are not from the camps, representatives from the semi-state institution Kizılay usually sign off as observers. However, its neutrality as an observer of the returns has been criticised by IGO and NGO representatives and legal professionals. Thus, we see that non-state actors and IGOs have potentially been utilised to serve state deportation measures of questionable legality.

Almost all interviewees described progress regarding cooperation, divisions of labour and procedural processes after initial challenges. They described improved governance resulting

\footnotetext{
${ }^{41}$ Interview (SRII-Meso-Küçükkuyu/Çanakkale-06) by author with the regional office representative of an IGO, Izmir.

${ }^{42}$ BBC, "Türkiye ABD merkezli yardım kuruluşu Mercy Corps'un faaliyetini durdurdu," Website, $B B C, 8$ March 2017, available at https://www.bbc.com/turkce/haberler-turkiye-39205825 [last accessed 23 August 2019].

${ }^{43}$ Fethullah Gulen Terrorist Organization.

${ }^{44}$ Haberler, “Göç İdaresi Genel Müdürlüğünden protokol feshi açıklaması,” Website, Haberler, 14 June 2019, available at: https://www.haberler.com/goc-idaresi-genel-mudurlugunden-protokol-feshi-12142992-haberi/ [last accessed 23 August 2019].
} 
from coordination meetings where all relevant stakeholders participated. However, some interviewees said that these meetings did not always produce concrete results. Neither NGOs nor IGOs had decision-making roles but rather could only provide counselling and support to security actors.

It should also be reiterated that while the establishment of the DGMM represents a move toward de-militarisation and civil governance, border management is still dominated by state security actors. The DGMM's brief is subordinate to all security procedures. Therefore, assessing asylum seeker vulnerability is still primarily done by security actors at the borders. Where possible, authorised IGOs or NGOs assist and provide significant support in assessing vulnerability as it comes within their "care" remit.

\section{Conclusion}

Despite initial changes, border management in Turkey has remained centralised and overseen mainly by security actors. However, following the mass migration of Syrians, particularly since the "European Refugee Crisis" of 2015, a lack of capacity to handle the crisis saw new actors become involved. This crisis created complex policy needs for Turkish authorities who sought to both keep full power over border management by devising procedures to retain regulative capacity, and release implementing exclusivity. To this end, state actors have increased their capacity to fulfil management requirements and IGOs and non-state actors have increased service provision capacities and taken limited roles in providing "care" services. Given the politicised and incomplete nature of Turkey's transitions within MLG, the future status of Turkey's border governance remains an open question.

This analysis places Turkey into Type II MLG at present. However, the practices that constitute this model of governance, since 2011, appear largely as an expression of changing logic within the state where civil society actors are transformed from passive objects to be acted upon into entities that the state can utilise for its own policy objectives. These actors therefore take up or share the responsibility of the state once they are authorised to do so. Similarly, IGOs, notably with their expanded responsibilities, undertake similar roles to NGOs - or as in the case of the EU, provide the bulk of the financial support. The EU's role has complicated Turkey's migration and border management. Contradictory policies and messaging have seen border management become a key foreign policy tool since 2015, with a return to securitization.

\section{References}

Anna Triandafyllidou and Angeliki Dimitriadi, "Governing Irregular Migration and Asylum at the Borders of Europe: Between Efficiency and Protection," Imagining Europe (6), Istituto Affari Internazionali; Criminal Justice, Borders and Citizenship Research Paper No. 2602712, 2014, Vol 6, p. 1-34.

BBC, “Türkiye ABD merkezli yardım kuruluşu Mercy Corps'un faaliyetini durdurdu," Website, $\quad B B C, \quad 8$ March 2017, available at https://www.bbc.com/turkce/haberler-turkiye-39205825 [last accessed 23 August 2019]. 
Beste İşleyen, “Turkey's Governance of Irregular Migration at European Union Borders: Emerging Geographies of Care and Control," Environment and Planning D: Society and Space, 2018, Vol. 36(5), p. 849-866.

Bianca Benvenuti, "The Migration Paradox and EU-Turkey Relations," IAI Working Papers, 17 January 2017, available at: http://www.iai.it/sites/default/files/iaiwp1705.pdf [last accessed 10 April 2019].

Deniz Sert, "Turkey's Integrated Border Management Strategy," Turkish Policy Quarterly, 2013, Vol. 12(1), p. 173-179.

DGMM, "Number of Irregular Migrants Who Have Been Captured by Years," Website, Republic of Turkey Ministry of Interior Directorate General of Migration Management, 29 April 2019, available at: http://www.goc.gov.tr/icerik6/irregular-migration $915 \quad 1024 \quad 4746$ icerik[nn1] [last accessed 5 May 2019].

European Commission, "A European Agenda on Migration," Website, European Commission, 15 May 2015, available https://ec.europa.eu/home-affairs/sites/homeaffairs/files/what-we do/policies/european-agenda-migration/background information/docs/glossary for the european agenda on migration en.pdf [last accessed 19 February 2019].

European Commission, "The EU-Turkey Joint Action Plan," Website, European Commission, 15 October 2015, available at: http://europa.eu/rapid/press-release MEMO-15-5860 en.htm [last accessed 7 April 2019].

European Commission, "A New Partnership Framework with Third Countries under the European Agenda on Migration,” Website, European Commission,7 June 2016, available at: https://eurlex.europa.eu/resource.html?uri=cellar:763fod11-2d86-11e6-b497-01aa75ed71a1. o001.02/DOC 1\&amp;format=PDF [last accessed 4 February 2018].

European Council, “The EU-Turkey Statement," Website, European Council, 18 March 2016, available at: https://www.consilium.europa.eu/en/press/press-releases/2016/03/18/eu-turkey-statemen t/ [last accessed 7 April 2019].

European Council, "The Treaty of Amsterdam Protocols," Website, International Democracy Watch, 2 October 1997, available at: http://www.internationaldemocracywatch.org/attachments/313 Amsterdam\%20Treaty\%2 o-\%20Protocols\%201997.pdf [last accessed 3 April 2019].

Gerda Heck and Sabine Hess, "Tracing the Effects of the EU-Turkey Deal the Momentum of the Multi-layered Turkish Border Regime," Movements Journal for Critical Migration and Border Regime Studies, 2017, Vol. 3(2), p. 35-56.

Fırat Genç, Gerda Heck, and Sabine Hess, "The Multi-layered Migration Regime in Turkey: Contested Regionalization, Deceleration and Legal Precarization," Journal of Borderlands Studies, 2018, Vol 34(4), p. 489-508. 
Haberler, "Göç İdaresi Genel Müdürlüğünden protokol feshi açlklaması," Website, Haberler, 14 June 2019, available at: https://www.haberler.com/goc-idaresi-genel-mudurlugunden-protokol-feshi-12142992-hab eri/ [last accessed 23 August 2019].

IOM, "The International Organization for Migration and Integrated Border Management," Website, International Organization for Migration, 2015, available at: https://www.iom.int/sites/default/files/our work/DMM/IBM/updated/O5 FACT SHEET Integrated Border Management 2015.pdf [last accessed 3 May 2019].

Katherine Daniell and Adrian Kay, "Multi-level Governance: An Introduction," in Katherine A. Daniell and Adrian Kay (eds.), Multi-level Governance: Conceptual Challenges and Case Studies from Australia, Canberra, the Australian National University Press, 2017, p. 3-32.

Liesbet Hooghe and Gary Marks, "Types of Multi-level Governance," Website, European Integration Online Papers, Vol 5(11), 2001, available at: http://eiop.or.at/eiop/texte/2001-011a.htm [last accessed 1 May 2019].

Liesbet Hooghe and Gary Marks, "Unravelling the Central State, But How? Types of Multilevel Governance," American Political Science Review, 2003, Vol. 97 (2), 2003, p. 233-243.

Marion Panizzon and Micheline van Riemsdijk, "Introduction to Special Issue: Migration Governance in an Era of Large Movements, a Multi-Level Approach," Journal of Ethnic and Migration Studies, 2018, Vol 49(8), p. 1225-1241.

Nefise Ela Gökalp Aras, “A Bio-political Governance: The European Union's Policy on Irregular Transit Migration at the Borders," in Assel Tutumlu and Gaye Güngor (eds.), International Political Economy: Multilateralism in Global Governance: Formal and Informal Institutions, Berlin, Peter Lang Publishing, 2016, p. 197.

Nefise Ela Gökalp Aras and Zeynep Şahin Mencütek, Border Management and Migration Controls Turkey- Country Report, Multilevel Governance of Mass Migration in Europe and Beyond Project (\#770564, Horizon2020) Report Series, 2019, available at: https://www.respondmigration.com/wp-blog/border-management-migration-controls-turk ey-report [last accessed 6 February 2020].

Nefise Ela Gökalp Aras and Zeynep Şahin Mencütek, "Evaluation of Irregular Migration Governance in Turkey from a Foreign Policy Perspective," New Perspectives on Turkey, 2018, Vol. 59, p. 63-88.

RESPOND Project, Website, RESPOND, available at: https://www.respondmigration.com/ [last accessed 4 May 2019].

Stephen Castles, "The Migration-Asylum Nexus and Regional Approaches," in Susan Kneebone and Felicity Rawlings-Sanae (eds.), New Regionalism and Asylum Seekers: Challenges Ahead, London, Berghahn Books, 2007, p. 25-42.

The UN General Assembly, "New York Declaration for Refugees and Migrants,” Website, The United Nations, 3 October 2016, available at: 
https://www.un.org/en/development/desa/population/migration/generalassembly/docs/gl obalc\%20ompact/A RES 71 1.pdf [last accessed 7 April 2019].

UNHCR, "Figures at a Glance," Website, United Nations High Commissioner for Refugees,19 June 2018, available at: https://www.unhcr.org/figures-at-a-glance.html [last accessed 5 March 2019].

UNHCR, "Turkey Fact Sheet,” Website, United Nations High Commissioner for Refugees, September 2018, available at: https://data2.unhcr.org/en/documents/download/66510 [last accessed 10 May 2019].

UNHCR, "Total Persons of Concern by Country of Asylum," Website, United Nations High Commissioner for Refugees, 2 May 2019, available at: https://data2.unhcr.org/en/situations/syria [last accessed 4 May 2019].

William Walters, "Reflections on Migration and Governmentality," Journal for Critical Migration and Border Regime Studies, 2015, available at http://movements-journal.org/issues/o1.grenzregime/O4.walters--migration.governmentali ty.html [last accessed 10 August 2019]. 